\title{
CURRENT CHALLENGES OF GROCERY MARKET AND KEY DIRECTIONS OF DEVELOPMENT OF AGRICULTURE IN GEORGIA
}

Badri Gechbaia ${ }^{1}$, Dr. of Economics, Associate Professor; Eter Kharaishvili ${ }^{2}$, Dr. of Economics Sciences, Professor; Gela Maumladze ${ }^{3}$, Dr. of Economics, Professor and Ketevan Goletiani ${ }^{4}$, Dr. of Techniques, Professor

Abstract. The work deals with the need to substantiate topicality of research of grocery market and key directions of development of agriculture. The conclusion is made which states that the level of productivity in Georgian agriculture is low. Based on the analysis, causes of low productivity of the industry and low level of development of grocery markets is assessed: low level of competitiveness of agricultural products, impediments for Georgian products to enter grocery markets, underdeveloped grocery supply chain, absence of usage of modern technologies and technological opportunities in agricultural sector, small share in the budget for funding agriculture, incomplete and ambiguous regulatory laws, low level of compatibility with legislation of international markets, underdeveloped system of insurance in agriculture etc.

Strengths and weaknesses of development of Georgian agriculture are revealed through SWOT analysis, as well as opportunities and threats.

Factors of low pace in development of agriculture and limited opportunities for farmers on grocery markets are determined by the "quality of urgency-impact" matrix, by using the scheme of priorities, needs of priority development of agriculture are revealed.

Conclusions and recommendations are suggested as a result of the research concerning current challenges of grocery markets and needs of priority development of Georgian agriculture.

Keywords: grocery markets, Georgia, agriculture, quality of urgency-impact, priority development. JEL code: Q130.

\section{Introduction}

Grocery provision is one of the main prerequisites of welfare in society. As of today, populations of many countries of the world experience low level of supply with grocery and achieving food security is regarded as one of the main challenges. Development of grocery markets can be considered as the key solution of this problem, where the main supplier of products will be highly productive agriculture. It is substantiated by researchers that development of agriculture is necessary for achieving economic growth, especially in developing countries.

In Georgia, development of highly productive agriculture based on demands on grocery markets is extremely important due to several factors: 1 . villages account almost half of the population $(41,7 \%) ; 2$. the industry employs $48,6 \%$ of the employees, the number of self-employed is especially high; 3 . the share of agriculture in GDP is $8,2 \%$; 4 . the level of grocery self-provision is low (wheat - $15 \%$, corn - $64 \%$, vegetables - $65 \%$, meat - $46 \%$, milk and dairy products - $82 \%$ etc.); 5 . there is a significant disproportion between import and export of agricultural goods, the amount of import exceeds export four times; 6 . there is high level of poverty in villages - according to 2017 data $21,9 \%$ of the population is beneath the level of absolute poverty. 7 . there is high level of gender inequality in villages. As statistical evidence and rigorous studies conducted by researchers and non-governmental organizations suggested gender inequalities in employment, education and income distributions still prevails in Georgia. Not all groups in society have equal access to employability and entrepreneurial opportunities etc.

Besides, it is worth noting that export countries for Georgian agricultural goods are mainly European and post-soviet. The level of competition on markets of these countries is rather high. On 
the other hand, most of the Georgian agricultural products have low level of competitiveness. Georgia has signed trade agreement with Europe, which envisages fulfilment of additional obligations. For Georgia, it is still difficult to meet European market requirements. Besides the above-mentioned factors, it is unclear or does not exist legal basis; Georgian products fail to meet requirements for entering new markets.

Hence, almost half of the Georgian agricultural sector employees create small share of GDP, which refer to low productivity of the industry. Moreover, the level of development of agriculture is insufficient for overcoming poverty and high share of import threatens food security of the country. It is expected that in parallel with population growth and rising incomes, demand on agricultural goods will also increase. In order to satisfy increased demand and solve aforementioned problems, drastic transitions will be necessary in Georgian agricultural industry. These transitions will require revealing the potential of production of agricultural goods and determining priorities based on industry traditions and trends with implementing integrated strategies and diverse approaches. This concept of development comes into compliance with EU rural development policy approaches until 2020. Its main goal is to reveal local priorities by the efforts of community, determine strategies for investments. Currently Georgia does not have unified policy for agricultural development. Comprehensive research of agricultural problems and grocery markets can play key role in elaboration of the policy of agricultural development. Besides, recommendations elaborated based on the research will contribute to diversification of economy, growth of productivity, rising competitiveness, development of agribusiness, investments, innovations and employment.

The goal of the research is to determine priorities of agricultural development of Georgia and elaborate recommendations on directions of grocery market by revealing current challenges of grocery market.

Research methods. The following methods have been used during the research:

- through bibliographical and empirical research, data derived from various sources is evaluated: National Statistics Office of Georgia, ministries of agriculture and economics of Georgia, Parliament of Georgia, studies of Georgian and foreign scientists, analytical reports, publications and researches related to the industry;

- for selecting and grouping the data, identifying similarities and differences and revealing trends, methods of comparison, analysis, synthesis, induction etc. are used;

- as a qualitative research method, in-depth interviews with farmers and experts of agriculture is used;

- through SWOT analysis, strengths and weaknesses, as well as opportunities and threats of development of agriculture are identified;

- low pace of development of agriculture and factors of limited reach on grocery markets for farmers are revealed through the "quality of urgency-impact" matrix;

- by using the scheme of priorities, needs of development of agriculture are determined.

\section{Research results and discussion}

Georgia is a traditional agricultural country. Throughout history, this sector played a key role in grocery provision and improving welfare. However, during the last decades, the amount of production in agricultural industry of Georgia has decreased significantly. The pace of development of the industry even today is way behind other industries. Grocery markets and agricultural development in post-soviet countries are important factors for economic growth. Generally, it is widely accepted 
that economic growth through agricultural development in GDP decreases poverty more effectively than other industries.

According to the modern studies, development of grocery markets and grocery provision of population is directly correlated to the productivity in the industry. It is also important to take into consideration the trend of fluctuation of prices on agricultural goods. The Organization for Economic Co-operation and Development (OECD) and Food and Agriculture Organization of the United Nations (FAO) forecast of major agricultural goods, biofuel and fishery for 2024 indicates decrease of real prices for all agricultural goods during the next ten years. The growing production supposedly will be supported by productivity growth and lower input prices. Slowing demand increase will be combined with high agricultural production growth. In addition, in developing countries the major changes in demand are projected.

Effective functioning of grocery markets greatly depends on implementation of relevant economic policy. Supply of agricultural products to the population and provision of healthy nutrition is the main aim of agrarian policy. Reforms based on such policy will contribute to retention of sustainable grocery provision in the long run.

Development of agriculture is the main challenge of sustainable grocery provision in Georgia. According to 2017 data, added value in agricultural sector accounted to 5,1 bn. lari (Fig. 1). In case of retaining this trend, the added value in the sector will increase to 5,9 bn. lari in 2020.

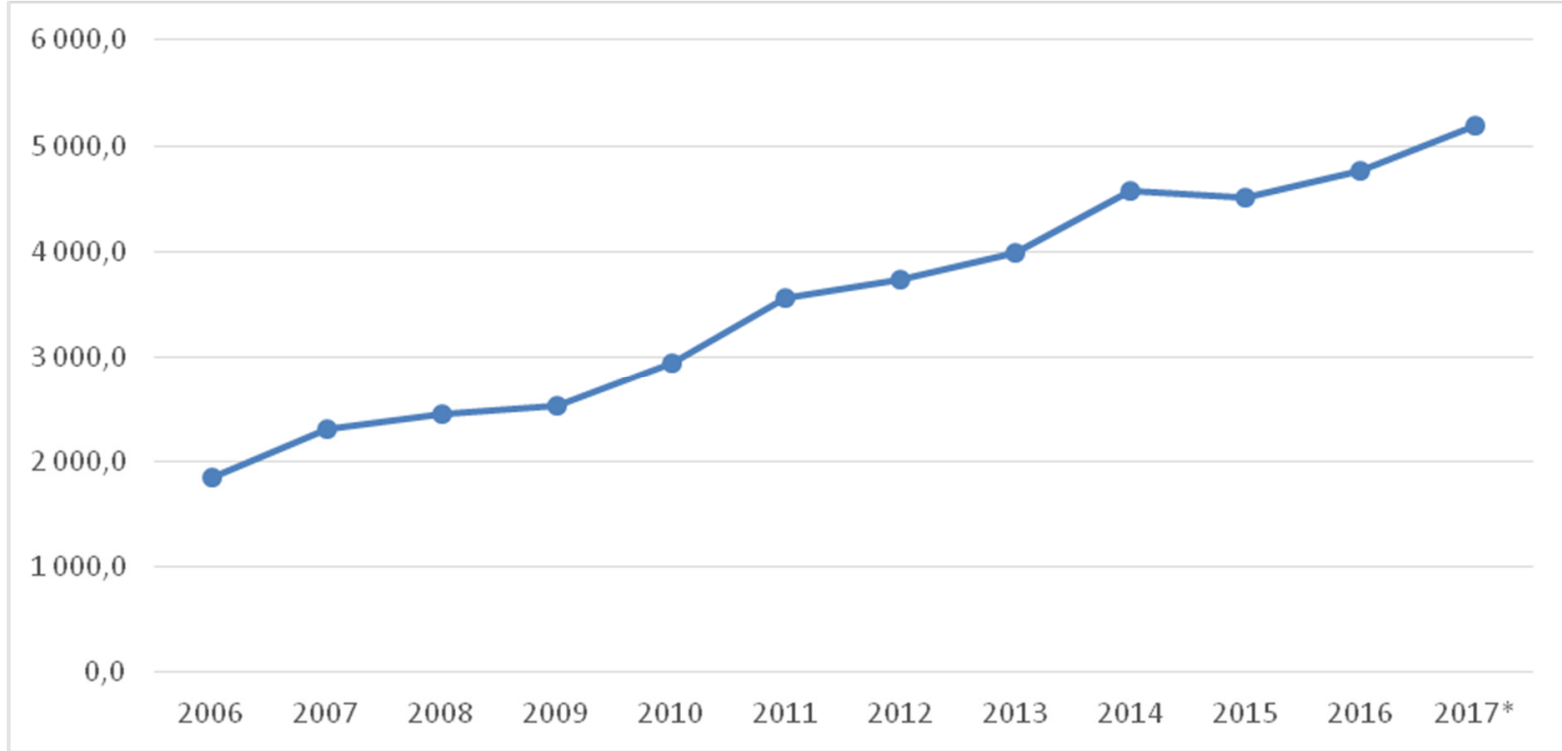

Fig. 1. Trend of growth of generated added value in agricultural sector ( $m$. lari)

Grocery markets will boost agribusiness growth pace. As of today, Georgian agricultural goods are intended mainly for internal market. This is confirmed by the ratio of export-import of agricultural goods and its share in export (Fig. 2; Fig. 3). 


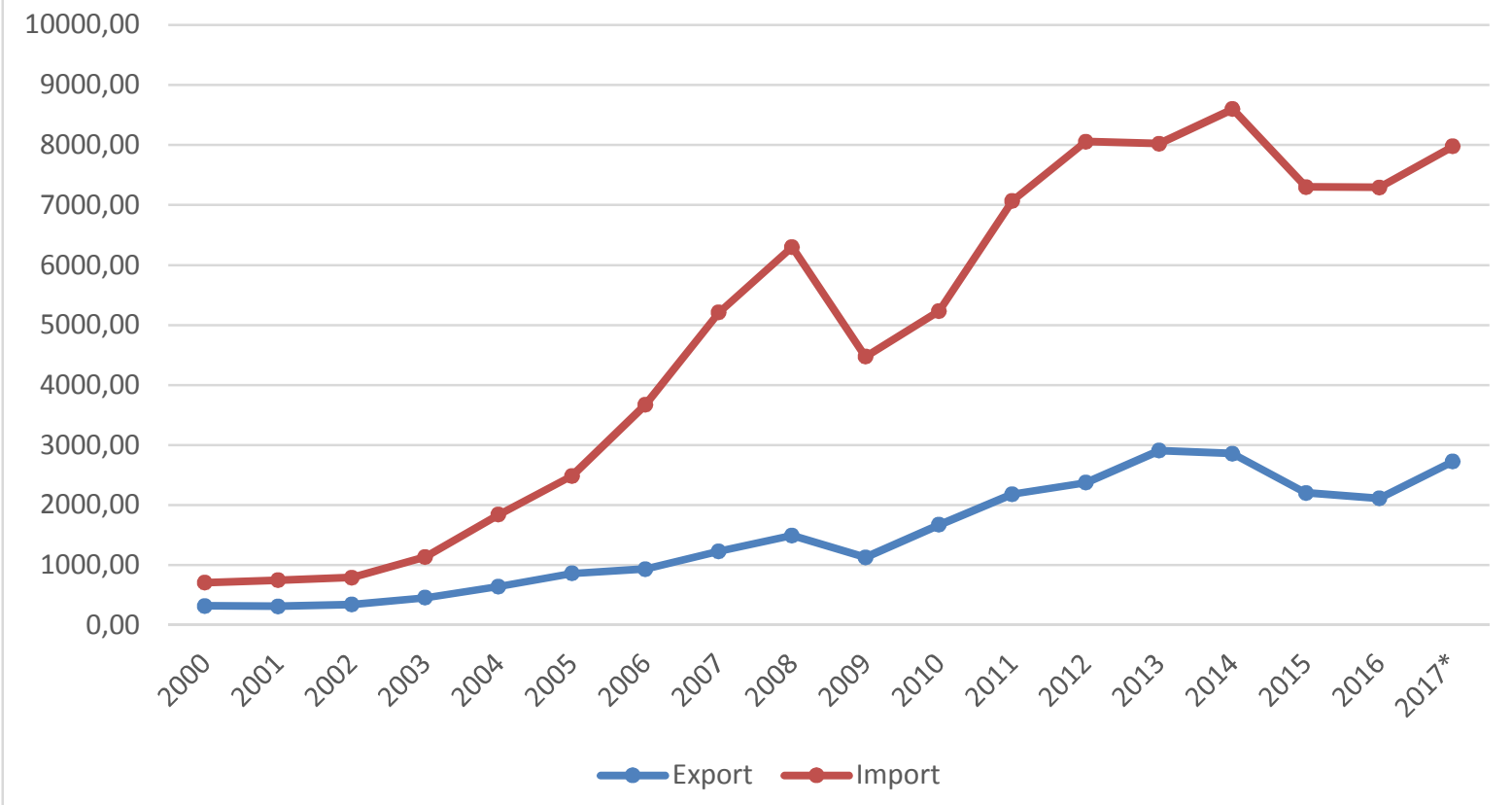

Fig. 2. Dynamics of export and import in Georgia in 2000-2017 (m. USD)

Comparative analysis of export and import data on agricultural goods revealed that according to 2017 data the amount of import significantly exceeded the amount of export and this trend remains unchanged. Also, structural changes in agricultural goods export were made lately. Nevertheless, the share of export of agricultural goods still remains small in overall amount of export. It fluctuates between 9-10\%.

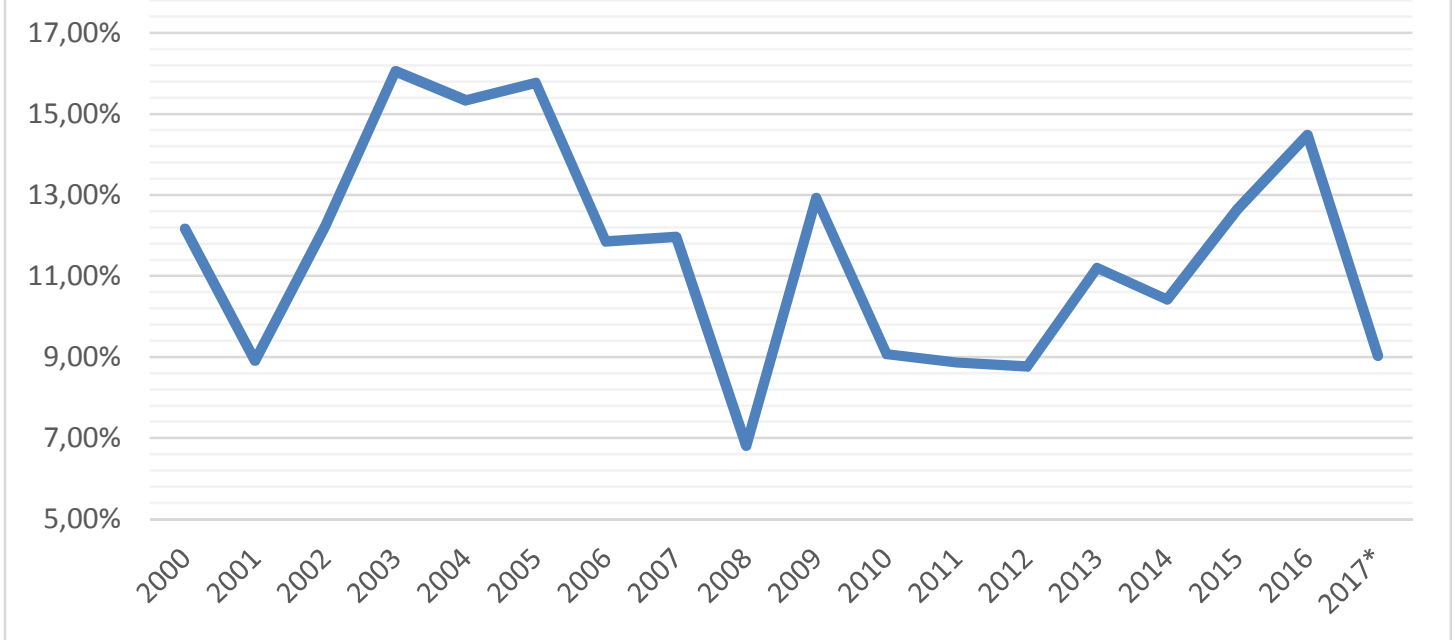

Fig. 3. Share of agricultural goods in export in 2000-2017 (\%)

We can single out several important trends in agricultural sector of Georgia: 1. big number of employed individuals in the industry creates small amount of added value; 2 . the pace of growth of production in agricultural industry increases threats in food security in short term prospect. As for the long run, it will not be enough for stable development of the industry and overcoming poverty; 3. the amount of import significantly exceeds the amount of export and local grocery markets are vulnerable to dumping prices; 4 . share of export of agricultural goods in overall export is small, which limits awareness of Georgian agricultural goods on international agricultural markets etc. 
Researchers conclude that growth of export allows developing countries overcome limited opportunities of reach on international and local markets. Also, this process boosts productivity and competitiveness.

The basis of development of agricultural markets is highly productive agriculture. In order to identify existing problems and prospects of development in Georgian agricultural industry, SWOT analysis was conducted. As a result of in-depth interviews with farmers and industry experts, strengths of Georgian agriculture were identified: quality soil for production of various types of products and environmental conditions; competence backed by the knowledge of the industry and traditions, growing interest from young generation towards agricultural industry etc. The following weaknesses were identified: low-productive species both in cattle breeding and plants; shortage of modern technologies; limited access to agro loans and low level of solvency among farmers; insufficient knowledge of modern technologies; absence of knowledge in drainage and irrigation systems; absence or malfunction of drainage and irrigation systems; falsified products on the markets; strong impact of environmental conditions; underdeveloped agri insurance systems etc.

Deriving from the SWOT analysis, there are the following opportunities for development of Georgian agricultural industry: creating new recycling enterprises; providing farmers with trainings; providing with business-consulting service; development of related and supportive industries; conducting programs of business loans and business grants aimed for small farmers; increasing accessibility on qualified professionals; improving species; creating cooperatives; acting against falsifications; developing agri insurance products; implementing modern technologies, decreasing damage of natural threats etc.

On the basis of grouping evaluations of experts, various threats must be reviewed. Natural threat is one of them (drought, flood, hail etc.); environmental pollution; migration and leak of knowledge; inertness of the population; epidemic diseases etc.

Low pace of development of agriculture and limited reach on grocery markets are caused by a group of factors. Evaluation of these factors was conducted by the "quality of urgency-impact" matrix (Fig. 4).

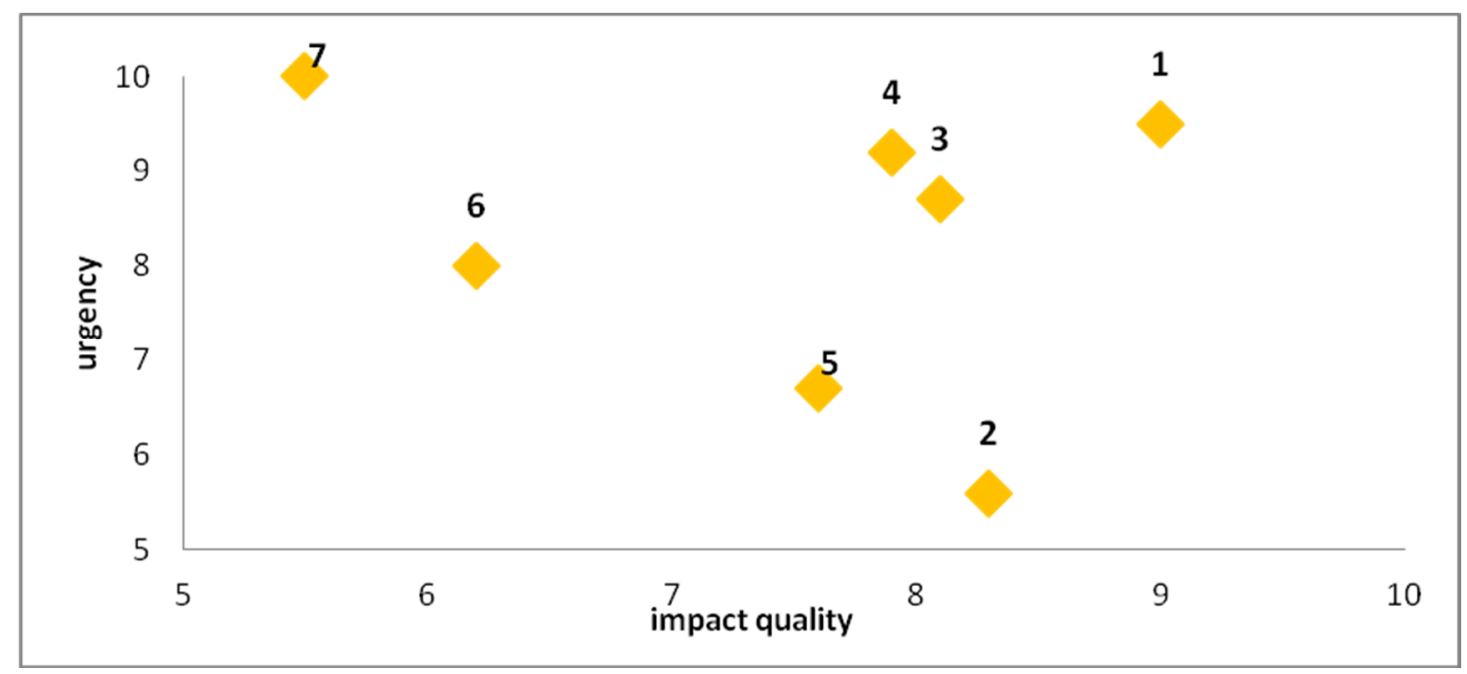

Fig. 4. Matrix of priorities "quality of urgency-impact"

It was revealed that low productivity and underdeveloped grocery markets of Georgian agricultural industry is caused by:

1) low competitiveness of products and impediments of entering grocery markets;

2) underdeveloped supply chain; 
3) low level of usage of modern facilities and technologies;

4) small share of funding of agriculture in the state budget;

5) shortage of qualified professionals;

6) incomplete and ambiguous regulatory laws, low level of compliance with international legislation on grocery markets;

7) underdeveloped agri insurance system etc.

According to the revealed factors, by using priority scheme, needs of Georgian agricultural industry were determined according to the following order (Fig. 5).

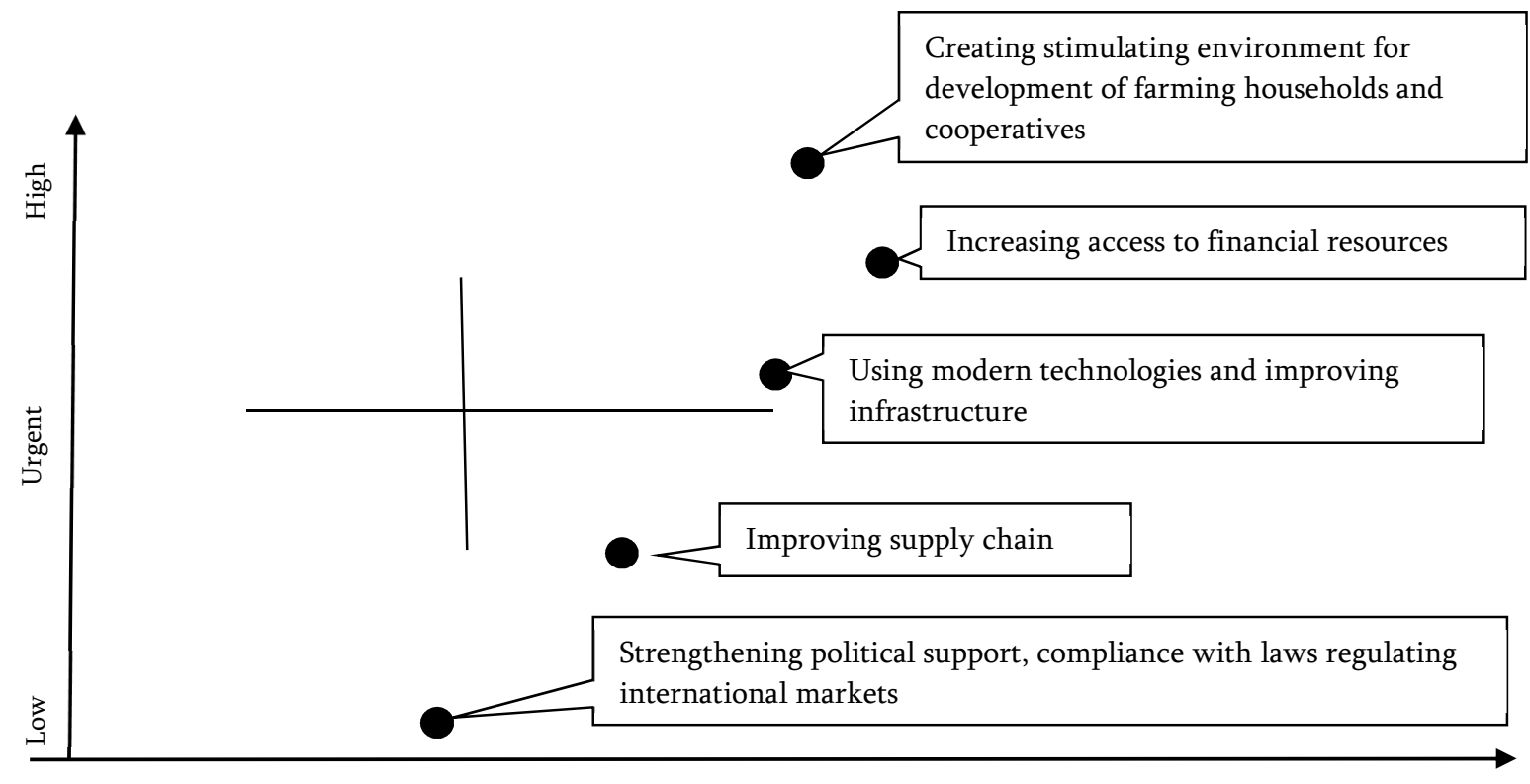

Fig. 5. Priority needs of development of Georgian agricultural industry

Creating favourable environment for farming households and development of cooperatives were determined as foremost premises for supporting agriculture. In its turn, it will have positive impact on development on land market. Land market in Georgia lacks development, most of farmers (75-80 \%) are of small scale and they have limited access to grocery market. Moreover, they are unable to use modern technologies for production, fail to improve species, lack relevant agricultural services that causes low productivity of the industry. Development of farming households is necessary both for supporting grocery markets and economy in general. It will result in raising the level of production in agricultural products which will boost diversification and market processes.

We should review increasing accessibility on financial resources as one of the most important priorities. In addition, sceptical attitude towards cooperatives can be noticed in the decision making processes in the banks. Raising the lower limit of the loans in case of cooperation will serve as a motivation for enlargement. Improving the availability of financing will, in turn, reveal the importance of cooperation and encourage banks to make affirmative decisions with respect to cooperatives. In addition, it is essential to identify financial and non-financial needs of development of cooperatives based on the research.

Using modern technologies and improving infrastructure stand on the third position in priorities of development of agriculture. In most countries development of agriculture, effectiveness of production and raising profitability are facilitated by using modern technologies. In this viewpoint, it is important to share experience of successful countries where development of the industry relies on latest expertise and modern technologies. 
Improving the supply chain will also significantly contribute to functioning grocery markets. In this point of view, the gap in supply chain between seller and buyer must be short which is of high importance. It will contribute to creating new connections between grocery reserves and the community. Reduction of loss on grocery also must be considered as important issue as this indicator equals to $30-40 \%$ of overall amount of grocery production. Due to this fact, considerable shortage occurs on agricultural consumer markets.

The following "critical points" are revealed in grocery supply chain in Georgia: risks are not assessed in agricultural production; agreements with business partners are questionable or ambiguous; rights on property of natural resources and utilization are not determined; there is No strategy for urban system of supply chain; issues of food security of local community need to be studied etc.

Political support also must be regarded as one of the priorities of development of grocery market and agriculture, as well as compliance with international legislation. The role of regions and municipalities in implementation of grocery provision policy is extremely weak. Activating grocery policy on local level will facilitate formation of new attitudes between the government and the society. Besides, increasing prices on grocery has become a subject of discussion among scientists and politicians. Raising prices is considered to be the main challenge on international grocery markets. $46 \%$ of consumer basket in Georgia is filled with grocery which is twice as more as the same indicator in Euro zone. Considering this, raising prices on grocery is especially sensitive for the society. Increasing prices on grocery exceeds minimum wage for living. Retaining optimal ratio between minimum wage for living, inflation and grocery prices will become one of the main solutions for sustainable development of agriculture.

Implementation of state policy in subsidies, stimulation and other programs will be necessary. Major legal drawbacks in legislation must be eliminated. In particular, land code must come into force; law on household farming holds must be passed. Besides, a number of laws require improvement, such as grocery provision and harmlessness, laws concerning grocery safety and their compliance with European legislative space.

Systematic approach towards development of agriculture is foremost prerequisite for development of grocery markets. Development of agriculture based on such concept and priority needs will provide stable growth of quality and safe production of agricultural goods, eradication of food shortage, substituting import with local production, improving welfare of population.

\section{Conclusions, proposals and recommendations}

- There are low quotients of self-provision with main agricultural goods in Georgia, which threatens the country's food security. Development of agriculture and grocery markets are the main solution for the problem.

- Low level of production in Georgian agriculture industry and underdeveloped grocery markets are caused by the following factors: low level of competitiveness of agricultural goods; impediments for Georgian product for entering grocery markets; underdeveloped grocery supply chain; absence of modern technologies in agricultural production; small share of funding in the budget; incomplete and ambiguous legislation and its low compatibility with international legislation; underdeveloped agri insurance system etc. It is necessary to determine priority needs and elaborate development strategies based on the revealed factors. 
- Derived from the priority scheme, development of Georgian agricultural industry should be carried out according to the following order: 1. creating favourable environment for development of farming households and cooperatives; 2 . increasing accessibility on funding; 3 . improvement of grocery supply chain by using relevant mechanisms; 4. strengthening political support for agriculture and grocery markets, modifying Georgian legislation for compliance with legislation regulating international markets.

- There is a direct correlation between grocery markets and agriculture. Strategy for development of agriculture must be elaborated with consideration of grocery markets, systematic and comprehensive approaches. Agricultural development strategy based on trends of grocery markets and priority needs will provide quality and safe growth in agricultural production, overcoming poverty in villages, food security, elimination of shortage on grocery, replacing import with growth of local production, improving welfare of the population.

- Political and financial support of grocery markets and agriculture is rather scarce. It is necessary to pass land code and law on farming households, improving legislation on grocery safety and harmlessness. It is also expedient to elaborate ways of budgetary support.

\section{Bibliography}

1. Agriculture of Georgia 2017, Tbilisi, 2018, pg. 17.

2. Agriculture of Georgia 2017, Tbilisi, 2018, pg. 17.

3. Chiladze, I. THEORETICAL AND PRACTICAL ASPECTS OF PROFITABILITY FACTORIAL ANALYSIS. $11^{\text {th }}$ International Scientific Conference: Accounting and Finance: Science, Business and Public Sector Partnership. Journal: Science and Studies of Accounting and Finance: Problems and Perspectives, Volume 12, Number 1, pp. 12-18. 2018 http://erd.asu.It/ssaf/article/view/269

4. Dobermann, A. \& Nelson, R. 2013. Opportunities and Solutions for Sustainable Food Production. Sustainable Development Solutions Network Thematic Group on Sustainable Agriculture and Food Production.

5. Development and Integration of Education, Science and Business", Georgia, Tbilisi, 24-30 October, 2017.

6. Export-import of grocery. http://geostat.ge/index.php?action=page\&p_id=751\&lang=geo

7. Grocery balances. http://geostat.ge/index.php?action=page\&p_id=751\&lang=geo

8. Giovannucci, D., Scherr, S., Nierenberg, D., Hebebrand, C., Shapiro, J., Milder, J. \& Wheeler, K. 2012. Food and Agriculture: The future of Sustainability.

9. Gulnaz Erkomaishvili. Economic Policy Priorities for Development of Georgia. Tbilisi, 2016.

10. International Panel of Experts on Sustainable Food Systems. 2015. The New Science of Sustainable Food Systems - Overcoming Barriers to Food Systems Reform.

11. Kharaishvili, E., Challenges for Sustainable Food Security in Georgia, XV EAAE Congress in Parma: Towards Sustainable Agri-Food Systems: Balancing between Markets and Society, Parma, Italy, 29 August - 1 September 2017.

12. Kharishvili, E., Gechbaia, B., Tsiklashvili, N., Priorities of Socio-economic Development of Georgia and Ukraine: Innovative Approaches and Perspectives /International collective monograph, Chapter 2/ in STRATEGIC PRIORITIES FOR DEVELOPING UKRAINE AND GEORGIA: INNOVATION AND PARTNERSHIP. BATUMI 2018. p. 40.

13. Kharaishvili, E., The Impact of Preferential Agro Credit on the Development of Agribusiness in Georgia, 2018. ECOFORUM. Volume 7, Issue 1(14), 2018.

14. Kharaishvili, E., DIRECTIONS FOR IMPROVING THE SUPPLY CHAIN IN THE AGRO-FOOD SECTOR OF GEORGIA. Materials I International Scientific and Practical Conference „,Forsight-Management: Best World Practice

15. Kharaishvili, E., Challenges for Sustainable Food Security in Georgia, XV EAAE Congress in Parma: Towards Sustainable Agri-Food Systems: Balancing between Markets and Society, Parma, Italy, 29 August - 1 September 2017.

16. Labor and Unemployment in Georgia 2017. http://geostat.ge/cms/site_images/_files/georgian/labour/dasaqmeba-umushevroba \%202018.21.05_presrelizi_GEO.pdf

17. Natsvlishvili, I. (2017) Gender Inequality and Women's Entrepreneurship-Challenges and Opportunities (Case of Georgia). In: Bilgin M., Danis H., Demir E., Can U. (eds) Country Experiences in Economic Development, Management and Entrepreneurship. Eurasian Studies in Business and Economics, vol 5. Springer, Cham. pp. 491-505. 
18. Natsvlishvili, I., (2016). European Models of Farms Diversification and Current Challenges. International Journal of Business and Management Studies, 05(02):31-38 (2016). UniversityPublications.net. Available at http://universitypublications.net/ijbms/0502/html/B6R219.xml

19. Overall Production of Agricultural Goods, National Statistics Office of Georgia, geostat.ge/cms/site_images/_files/georgian/nad/agrobiznesi.xls

20. Renting, H. \& Wiskerke, H. 2010. New Emerging Roles for Public Institutions and Civil Society in the Promotion of Sustainable Local Agro-Food Systems.

21. Strategy of Development of Agriculture in Georgia 2015-2020. P. 11.

22. The Level of Life. http://geostat.ge/index.php?action=page\&p_id=187\&lang=geo

23. Thematic Group on Sustainable Agriculture and Food Systems of the Sustainable Development Solutions Network. 2013. Solutions for Sustainable Agriculture and Food Systems. Technical report for the post-2015 development agenda.

24. Trends in Agricultural Production Efficiency and Its Implications for Food Security in Sub-Saharan African Countries. Christian Nsiah, Baldwin Wallace, University Bichaka Fayissa Middle Tennessee State University, 2017. file:///C:/Users/eteri/Downloads/TrendsInAgriculturalProductionEffici_preview.pdf 